\title{
Perubahan Sosial Ekonomi Terhadap Eksistensi Batu Akik
}

\author{
Mayang \\ Andi Sukri Syamsuri \\ Universitas Muhammadiyah Makassar \\ andisukrisyamsuri@unismuh.ac.id \\ Muhammad Akhir \\ Universitas Muhammadiyah Makassar \\ muhammadakhir@unismuh.ac.id
}

\begin{abstract}
ABSTRAK
Setiapa masyarakat selalu mengalami yang namanya perubahan, baik perubahan yang terjadi secara lambat maupun perubahan yang terjadi secara cepat. Tujuan penelitian ini adalah (i) mengungkapkan faktor-faktor yang mempengaruhi perubahan sosial ekonomi masyarakat. (ii) mengungkapkan proses perubahan sosial ekonomi masyarakat dengan adanya Trend Batu Akik. Jenis penelitian ini adalah penelitian sosial budaya (PSB) dengan tipe deskriptif kualitatif, yaitu memberikan gambaran tentang perubahan sosial ekonomi terhadap keberadaan batu Akik di Masyarakat. Pengumpulan data dalam penelitian ini dilakukan dengan cara observasi, wawancara dan dokumentasi. Dalam penelitian ini responden di pilih langsung oleh peneliti yang disebut sasaran penelitian yaitu 8orang atau masyarakat selaku pembuat batu Akik.Hasil penelitian menunjukkan bahwa batu akik adalah salah satu pekerjaan yang bisa membawah perubahan pada masyarakat, selain bertani juga memiliki pekerjaan sampingan sebagai sumber mata pencaharian masyarakat untuk menopang kebutuhan keluarga yang sangat membantu perekonomian masayarakat Desa Pattappa. Dan selain kelebihan tersebut batu Akik juga memiliki kekurangan yang dimana masyarakat dalam membuat atau mengolah batu Akik menjadi batu permata hanya melakukan penularan perilaku dari masyarakat sebelumnya yang lebih dahulu menekuni pekerjaan tersebut.Adapun yang berperan penting dalam perubahan sosial ekonomi masyarakat di Desa Pattappa Kecamatan Pujananting Kabupaten Barru yaitu faktor keluarga, faktor lingkungan dan adanya penemuanpenemuan baru.
\end{abstract}

Kata Kunci : Perubahan, sosial, ekonomi, batu akik.

\section{PENDAHULUAN}

Sebagai negara yang berkembang, Indonesia tentunya selalu mengalami perubahan dengan seiringnya perkembangan zaman yang semakin modern. Setiap masyarakat selama hidupnya, akan mengalami yang namanya perubahan, perubahan tersebut bagi masyarakat yang bersangkutan maupun bagi orang-orang luar yang menelanya. Dengan demikian perubahan sosial merupakan segala perubahan pada lembaga kemasyarakatan didalam suatu masyarakat yang mempengaruhi sistem sosialnya, termasuk didalamnya nilai-nilai, sikap-sikap dan pola-pola perilaku diantara kelompok masyarakat.Perubahan-perubahan yang terjadi di dalam masyarakat juga tidak lepas dari perkembangan ekonomi masyarakat yang dimana diketahui bahwa Sosiologi 
ekonomi merupakan study yang mempelajari cara orang atau masyarakat dalam memenuhi kebutuhan mereka terhada barang dan jasa, dengan menggunakan pendekatan atau perspektif analisis sosiologi. Pendekatan sosiologi yang memahami dan menjelaskan kenyataan sosial, atau fenomena serta perubahan-perubahan yang terjadi dalam masyarakat termasuk dengan adanya fenomena Batu Akik ini.Dengan membumingnya pemberitaan batu Akik dengan harga yang fantastik menarik perhatian masyarakat Pattappa untuk menjadikan kebiasaannya dalam mengolah batu sebagai salah satu alternatif mata pencaharian, yang tidak bisa disanggah dengan fakta yang ada bahwa, masyarakat yang memiliki mata pencaharian bertani ini dengan penghasilan yang diterima yang kadang tidak kembali modal awal jika mengalami gagal panen, akan tetapi dalam mengolah batu biasa menjadi batu permata yang tidak membutuhkan modal besar akan tetapi memiliki nilai jual yang tinggi. Maka dari pengamatan ini dilihat adanya perubahan di masyarakat yaitu perubahan sosial dan ekonomi yang merupakan suatu perubahan kearah yang lebih baik, perubahan positif.

\section{LANDASAN TEORI}

Masyarakat secara historis bergerak dari masyarakat yang tinggal menuju masyarakat menetap (disebut masyarakat kota). Setiap saat masyarakat selalu mengalami perubahan. Jika dibandingkan apa yang tejadi saat ini dengan beberapa tahun yang lalu. Maka akan banyak ditemukan perubahan baik yang direncanakan atau tidak, kecil atau besar, serta cepat atau lambat. Perubahan-perubahan tersebut dilakukan sesuai dengan kebutuhan dan kondisi lingkungan sosial yang ada.Perubahan sosial dikalangan para sosiolog memiliki pengertian yang berbeda.Berbedanya pengertian perubahan sosial tersebut sebagai konsekuensi dari kekaburan yang sering dialami ahli sosial di dalam memberikan penjelasan tentang ruang lingkup, batasan pengertian dan aspek-aspek, terutama dalam perubahan sosial.Sebagai upaya untuk menghindari kesulitan tersebut, maka faktor utama yang paling penting untuk diketahui dan dipahami adalah tentang batas dan pengertian dari perubahan sosial itu sendiri.Menurut Mac Iver dalam Anwar dan Adang (2011:246), perubahan-perubahan sosial adalah ekspresi dari jiwa yang terwujud dalam cara-cara hidup dan berpikir, pergaulan hidup, agama, rekreasi, hiburan dan lembaga-lembaga kemasyarakatan di dalam suatu masyarakat, yang mempengaruhi sistem sosialnya, termasuk didalam nilai-nilai, sikap-sikap dan pola-pola perilaku diantara kelompok-kelompok dalam masyarakat. 
Secara umum penyebab dari perubahan sosial dibedakan atas dua golongan besar Selo Soemardjan dan Soelaiman Soemardi dalam Basrowi( 2005: 623)yaitu: Perubahan yang berasal dari dalam masyarakat, perkembangan ilmu pengetahuan, pengetahuan yang paling luas menghasilakn teknologi canggih yang mengubah kehiduan manusia. Penemuan-penemuan baru akibat perkembangan ilmu pengetahuan tersebut, baik berupa teknologi maupun berupa gagasan-gagasan menyebar ke masyarakat, dikenal, diakui, dan selanjutnya diterima serta menimbulkan perubahan sosial. Menurut Koentjraningratfaktor-faktor yang mendorong individu untuk mencari penemuan baru yaitu : (1). Kesadaran dari orang perorangan akan kekurangan dalam kebudayaannya. (2). Kualitas dari ahli dalam suatu kebudayaan dan (3).Perangsang bagi aktivitas-aktivitas pencipta dalam masyarakat.Masalah kependudukan yang menimbulkan perubahan sosial budaya pada umumnya adalah pertambahan penduduk akibat terjadinya urbanisasi dan sebaliknya, berkurangnya jumlah penduduk pada daerah-daerah yang di tinggalkan oleh orang-orang yang berurbanisasi tersebut. Urbanisasi penduduk ke kota-kota besar atau tempat yang menjanjikan harapan menimbulakan ketidak seimbangan antara luas daerah beserta sumber kehidupannya dengan jumlah penduduk yang ada.Dalam Anwar dan Adang,(2013:248). Perubahan jumlahpenduduk juga merupakan penyebab terjadinya peruabahan sosial, seperti pertambahan atau berkurangnya penduduk pada suatu daerah tertentu, seperti pertambahan penduduk pada suatu daerah dapat mengakibatkan perubahan pada struktur masyarakat, terutama mengenai lembaga-lembaga kemasyarakatan.Perubahan yang berasal dari luar masyarakat, pengaruh kebudayaan luar, dalam Anwar dan Adang, (2013:249). Adanya inteaksi langsung (tatap muka) antara suatu masyarakt dengan masyarakat lainnya akan menyebabkan saling pengaruh. Di samping itu, pengaruh dapat berlangsung pula memalui komunikasih satu arah, yakini menjamin timbulnya pengaruh satu budaya terhadap budaya lainnya.Suatu masyarakat dapat saja menolak, menyeleksi terlebih dahulu baru kemudian menyerap unsur yang sesuai.Dalam Anwar dan Adang, (2013:249). Peperangan yang terjadi antara satu masyarakat dengan masyarakat lain menimbulkan berbagai dampak, seperti halnya di timbulkan oleh adanya pemberontakan dan pertentang-pertentangan. Akan tetapi, dampak negatif yang di timbulkan oleh peperangan lebih dahsyat karena peralatan perang biasanya lebih canggih pula.Dalam Anwar dan Adang, (2013:249).Sebab-sebab yang berasal dari lingkungan alam fisik yang ada disekitar manusia sebab-sebab yang bersumber pada lingkungan alam fisik, disebabkan oleh tindakan-tindakan dari wargawarga masyarakat itu sendiri. 


\section{METODE PENELITIAN}

Jenis penelitian yang dilakukan penelitian kualitatif yang bertujuan memahami realitas sosioal terhadap perubahan sosial ekonomi masyarakat dengan adanya keberadaan batu akik di Desa Pattappa Kecamatan pujananting Kabupaten Barru. Informan ditentukan secara purpose sampling, teknik pengumpulan data yaitu observasi, wawancara, dan dokumentasi, kemudian dianalisis melalui tahapan pengumpulan data ( data collection), reduksi data (data reduction), penyajian data ( display data), penarikan kesimpulan (conclusion) dan menggunakan teknik keabsahan data triangulasi sumber,teknik, dan waktu.

\section{PEMBAHASAN}

Dalam perubahan sosial, unsur-unsur kemasyarakatan yang mengalami perubahan biasanya adalah mengenai nilai sosial, norma sosial, pola perilaku, organisasi sosial, kekuasaan, tanggung jawab, dan kepemimpinan. Dalam masyarakat maju atau masyarakat berkembang perubahan sosial berkaitan erat dengan perkembangan ekonomi.Banyak perubahan yang terjadi di masyarakat yang mempengaruhi perilaku dan kebiasaan untuk meningkatkan tarap dan pola ekonomi dalam keluarga, dan kebanyakan masyarakat mengambil kesempatan dan memanfaatkan perubahan-perubahan yang muncul yang sifatnya positif, salah satu dengan fenomena batu Akik yang melanda Indonesia dari sabang sampai merauke termasuk unik. Ini terjadi secara spontan, tiba-tiba dan massiveyang berasal dari berbagai daerah di Indonesia. Yang dimana sudah lama menjadi bagian dari masyarakat Indonesia, batu Akik kini kembali menjadi sebuah trend yang digandrungi banyak orang.Kegemaran masyarakat mengoleksi dan menggosok batu ini mulai mewabah lagi setelah beberapa saat sempat tidak pernah terdengar.Sehingga ada ketertarikan untuk meneliti fenomena batu Akik yang mempengaruhi perubahan sosial masyarakat, dan tidak bisa dipungkiri bahwa masyarakat yang berada di Desa Pattappa, juga demam batu Akik dan meradang keseluruh penjuru usia. Dan dengan adanya keberadaan batu Akik ini membawa dampak positif terhadap perubahan sosial dan ekonomi masyarakat. Dengan realita sekarang dapat dilihat bahwa masyarakat menemukan suatu pekerjaan sampingan selain bertani, akan tetapi dengan pekerjaan ini dalam mengolah batu biasa menjadi batu permata sangat menarik perhatian, karena pada awalnya hanya diambil sebagai pengisi kekosongan saat tidak berkebun dan hasil karya yang dihasilkan hanya dijadikan koleksi.Dengan adanya fenomena tersebut sehingga terjadi perubahan sosial yang terjadi dalam masyarakat yang dapat dibedakan atas 
beberapa bentuk, yaitu perubahan evolusi dan perubahan revolusi. (1) Perubahan evolusioner, evolusi adalah perubahan yang lama dengan rentetan perubahan kecil yang saling mengikuti dengan lambat. Dalam evolusi, perubahan terjadi dengan sendirinya tanpa rencana.Hal ini sebagai akibat usaha-usaha masyarakat untuk menyesuaikan diri dengan keperluan-keperluan, kedaan-keadaan, dan kondisi-kondisi baru yang muncul mengikuti pertumbuhan masyarakat.Misalnya, terjadinya musim kemarau yang berkepanjangan dan berakibat sulitnya mendapatkan penghasilan yang cukup hingga membuat banyak anggota masyarakat nekat melakukan tindakan-tindakan kriminal, hanya agar dapat memenuhi kelangsungan hidupnya.( 2) Perubahan revolusioner, Berbeda halnya dengan perubahan yang bersifat revolusi, dimana perubahan berlangsung secara tepat dan tidak ada kehendak atau perencanaansebelumnya. Perubahan revolusi dapat diartikan sebagai perubahan-perubahan sosial yang mengenai unsur-unsur kehidupan atau lembaga-lembaga kemasyarakatan yang berlangsung relatif cepat.Peruabhan-perubahan tersebut dapat terjadi karena sudah ada perencanaan sebelumnya atau mungkin tidak berguna sekali, perubahan revolusi sering kali diawali oleh ketergantungan-ketergantungan atau konflik dalam tubuh masyarakat yang bersangkutan, ketegangan-ketegangan itu sulit untuk dihindari.Desa Pattappa tepatnya ada enam dusun jadi pusat perhatian pengungjung yang datang didaerah tersebut. Yang dimana di daerah ini masyarakat memproduksi batu akik, dan batu yang diolah menjadi batu akik adalah batu asli dari daerah tersebut, karena daerah Pujananting yang tepatnya di Desa Pattappa identik dengan batuan karena berada di daerah pegunungan serta tempat yang terpencil yang didominasi oleh batu dan tumbuhan serta hewan peliharaan masyarakat. Daerah ini memiliki banyak batu yang indah kemudian bisa diolah menjadi batu cincin yang memiliki nilai jual yang tinggi serta batu-batu didaerah ini banyak disukai atau digemari oleh masyarakat Papua, dan tinggihnya permintaan dari berbagai daerah karena batu yang ada di Desa Pattappa adalah batu tua yang keras dan tidak mudah retak serta memiliki keindahan dan ketertarikan tersendiri.Batu Akik memiliki bahasa ilmiah yakni gemstone (batu mulia) atau precious stone (batu setengah mulia).Seperti yang dijelaskan oleh Kemala Wijayanti selaku asisten dosen dari Fakultas Teknik Geologi, batu Akik sebetulnya mineral yang keterbentukannya dari pembetukan magma. Karena terbentuknya memiliki perbedaan tempat, kedalaman, dan pembekuannya, maka dari itu jenis dan warnanya beragam karena memiliki ikatan kimia yang beda di setiap batunya. Dan yang mempengaruhi warna dan kekerasannya itu bisa dari temperatur keterbentukannya, komposisi kimia magma dan tekanan.Sudah lama 
menjadi bagian dari masyarakat Indonesia, batu Akik kini kembali menjadi sebuah trend yang digandrungi banyak orang, tua maupun muda.Ada banyak hal yang membuat seseorang suka dengan batu Akik. Berdasarkan alasan seseorang menyukai batu Akik, Sujarwanto Rahmat M. Arifin, salah seorang komisioner Komisi Penyiaran Indonesia yang menaruh perhatian pada batu Akik sejak 4 tahun lalu, mengelompokkan penggemar batu di Indonesia menjadi 3 jenis diantaranya:

\section{Alasan mistis}

Penggermar mistis adalah orang-orang yang menyukai batu Akik cincin karena halhal mistis yang dipercaya terkandung dalam batu-batu tersebut.Biasanya orang-orang tersebut mempercayai bahwa sebuah jenis batu bisa mendatangkan kekayaan, membawa pamor, atau memberi proteksi magis.Atau juga dipercaya bahwa dalam sebuah batu terdapat makhluk gaib yang perlu dirawat sedemikian rupa untuk mencapai satu tujuan tertentu.Mengenai orang-orang yang suka batu Akik karena unsur kleniknya dikatakan Sujarwanto, Memang ada sebagian orang yang suka batu Akik karena kepercayaan kleniknya. Untuk hal ini merupakan tugas pemuka-pemuka agama untuk terus menyuarakan apa yang harusnya menjadi pedoman dalam berkegiatan, termasuk kegemaran akan batu Akik.

\section{Penggemar energi alam batu Akik}

Berbeda dengan penggemar mistis, penggemar energi alam batu Akik menaruh kepercayaan akan adanya kekuatan magis atau makhluk gaib dalam batu-batu itu. Penggemar kategori ke dua ini meyakini bahwa sebagaimana benda alam lain, batu-batu tersebut juga memiliki energi sesuai dengan kandungan mineralnya.Energi dari kandungan-kandungan mineral dalam batu-batu tersebut diyakini akan berinteraksi dengan energi dari kandungan-kandungan mineral dalam tubuh manusia pemakainya. Hasilnya bisa bermacam-macam tergantung dari jenis batu apa yang dikenakan. Misalnya, sebuah batu dengan kandungan mineral dan energinya bisa membuat pemakainya menjadi lebih tenang.

\section{Penggemar keindahan}

Warna, bentuk, dan ukuran batu menjadi perhatian utama dari penggemar jenis ini. Sebagian penggemar keindahan batu Akik akan menilai sebuah batu dari bagaimana batu tersebut dapat dipasangkan dengan busana-busana yang dimilikinya. Penggemar ini akan memperhatikan segi fesyen dari batu cincin.Selain Penggemar keindahan dari sisi fesyen, ada juga penggemar keindahan batu cincin sebagai benda pajangan. Penggemar ini akan melihat keindahan batu cincin sebagai sesuatu untuk dinikmati mata, bukan untuk 
dicocokkan dalam cara berpenampilan.Beberapa tahun yang lalu, kegemaran masyarakat mengoleksi dan menggosok batu ini mulai mewabah lagi setelah beberapa saat sempat tidak pernah terdengar. Dan dengan adanya keberadaan batu Akik ini membawa dampak positif terhadap perubahan sosial dan ekonomi masyarakat di Kelurahan Patappa .Perubahan ini merubah tarap perekonomian masyarakat, salah satu dari keluarga kurang mampu menjadi keluarga sederhana yang mencukupi kebutuhan ekonomi keluarga, dan suatu perubahan terjadi karena dipengaruhi oleh faktor-faktor yang terjadi dalam suatu masyarakat salah satu dari beberapa fakor tersebut adalah penemuan-penemuan baru. Suatu proses sosial yang terjadi dalam jangka waktu yang tidak terlalu lama disebut dengan inovasi atau innovation. Proses tersebut meliputi suatu penemuan baru, jalannya unsure kebudayaan baru yang tersebar kelain-lain bagian masyarakat, dan cara-cara unsure kebudayaan baru yang diterima, dipelajari, dan akhirnya dipakai dalam masyarakat yang bersangkutan.Penemuan-penemuan baru sebagai sebab terjadinya perubahan-perubahan dapat dibedakan dalam pengertian-pengertian discovery dan invention.Discovery adalah penemuan unsur kebudayaan yang baru, baik berupa alat, ataupun yang berupa gagasan yang diciptakan oleh seorang individu atau serangkaian ciptaan para individu.

Di zaman modern sekarang ini banyak berita serta informasi yang disampaikan oleh seseorang baik melalui media sosial maupun media massa, salah satunya adalah televisi yang diminati oleh masyarakat Desa Pattappa yang merupakan media sumber informasi yang hampir seluruh masyarakat mengetahuinya, dan berbagai informasi serta berita yang didapat dari media tersebut. Di kalangan masyarakat Pattappa menemukan suatu pekerjaan baru sebagai pekerjaan ganda atau yang biasa dikenal dengan nama pekerjaan sampingan oleh masyarakat Pattappa, dari media massa ini banyak memberikan manfaat pada masyarakat karena masyarakat termotivasi serta memanfaatkan berita-berita yand didapatkan dri informasi tersebut kedalam keluarga mereka, salah satunya adalah dengan membumingnya pemberitaan batu Akik banyak masyarakat yang memanfaatkan kesempatan tersebut untuk ikut berpartisipasi membuat batu Akik.Dari persepsi responden terhadapa batu Akik, dapat diketahui informasi dan kelebihan apa yang didapat masyarakat setelah bekerja sebagai pembuat batu Akik, penilaian responden terhadapa batu Akik mengenai informasi pekerjaan sampingan selain bertani juga berprofesi sebagai pengrajin batu Akik dalam hal ini menyangkut perubahan sosial ekonomi masyarakat sehingga secara langsung maupun tidak langsung dapat menimbulkan daya tarik tersendiri oleh masyarakat terhadap batu Akik selaku pembuat batu Akik. 
Masyarakat yang berprofesi sebagai petani dan hanya mendapatkan pendapatan yang tidak mampu mencukupi kebutuhan biaya keluarga mereka.Karena sebagian dari mereka tidak memiliki lahan pertanian atau perkebunan dan hanya ikut membantu pemelik sawah atau kebun dengan upah seadanya.Dengan demikian masyarakat Desa Pattapa selaku pembuat batu Akik mengaku bahwa dengan keberadaan batu Akik di tengah-tengah lingkunagn mereka sangat mendukung dan memberikan manfaat kepada mereka masyarakat yang tidak memiliki lahan pertanian ataupun perkebunan.Masyarakat yang berpropesi sebagai pembuat batu akik mengalami perubahan sosial ekonomi, dari hasi penelitian menyadari bahwa kelebihan yang didaparkan dari pekerjan dalam membuat batu Akik adalah meningkatkan tarap prekonomian masyarakat dan juga membantu kesejahteraan keluarga mereka serta mempererat silatuhrahmi mereka selaku pembuat dan pembeli batu akik, dan adapun kekurangn dari perubahan sosial ekonomi masyarakat dengan adanya keberadaan batu akik ini di masyarakat Desa Pattappa adalah masyarakt lebih cenderung mengikuti kebiasaan masyarakat lain dalam artian mesyarakat Desa Pattapa lebih cenderung melakukan penularan perilaku terhadapa perkembangan yang ada.

Berdasarkan dari pengamatan peneliti pengamatan peneiti yang dilakukan di Desa Pattappa kecamatan Pujananting Kabupaten Barru.Peneliti mengamati sejumlah masyarakat yang sedang membuat Batu Akik yang menggunakan peralatan seadanya dan ada juga yang memiliki peralatan yang luamayan bagus peneliti melihat dan mengamati para masyarakat tersebut dalam menggosok batu cincin dan masyarakat benar-benar teliti serta hati-hati dalam mengolah batu Akik.Dan adapun dampak yang ditimbulkan dari pekerjaan membuat batu Akik adalah dari hasil penelitian melihat bahwa masyarakat membawa perubahan sosial ekonomi kedalam lingkungan masyarakat serta pada lingkungan keluarga mereka dan sebagian masyarakat menegembangkan bakat seninya serta membantu prekonomian kelurga merw32aeka dengan tujuan untuk memenuhi kebutuhan serta mensejahterakan keluarga mereka.Oleh karena itu kepalah keluarga sangat berperan penting untuk mempasilitasi anak dan istri mereka, kepalah keluarga sebagai penopang keluarga memiliki tanggung jawab penuh terhadap kelangsungan hidup anak dan istrinya.Untuk melakukan gerakan perubahan sosial khususnya prubahan sosial konomi. 


\section{KESIMPULAN}

faktor atau sebab-sebab yang berperan penting terhadap perubahan sosial di masyarakat Desa Pattappa Kecamatan Puajananting Kabupaten Barru adalahlah diantaranya bagi individu, pendorong tersebut adalah penemuan-penemuan baru yang merupakan unsur kebudayaan baru baik yang berupa alat, ataupun yang berupa gagasan yang diciptakan oleh seorang individu. Dan setiap masyarakat menginginkan kesejahteraan pada keluarga mereka dan salah satu faktor kepalah keluarga menekuni suatu pekerjaan karena keluarga yang merupakan unit terkecil dari masyarakat dan selalu ingin melakukan perubahan kearah yang lebih baik demi kesejahteraan dan kedamaian keluarga mereka .

\section{DAFTAR PUSTAKA}

Andry Pramudya. (2012). Defenisi Masyarakat. (Online) http: // Sosial Sosiologi. Blogspot.com/2012/12/defenisi masyarakat.html (Adhisoro sukirto).

Anwar Yesmil dan Adang.(2013) .Sosiologi Untuk Universitas. Bandung : PT Refika Aditama.

Basrowi.(2005) .Perubahan Sosial.Yogyakarta : Prenada Media Group.

Graha, Doddy Setia. (1987). Batuan Dan Mineral.Bandung : Nova.

Guba dan Lincon.(1981). Metode Penelitian Kualitatif \& Kuantitatif. Bandung: Rosdakarya.

Herimanto dan Winarno.(2014). Ilmu Sosial \& Budaya Dasar. Jakarta : Bumi Aksara.

Judistira K. Garna. (1996). Ilmu-ilmu Sosial Dasar-Konsep-Posisi. Bandung : Program Pascasarjana Universitas Padjadjaran.

Martono Nanang. (2011). Sosiologi Perubahan Sosial.Jakarta : Rajawali Pers.

Moleong, J.Lexy. (2007). Metode Penelitian Kualitatif.Bandung : Rosdakarya.

Narkowo Dwi dan Susanto Bagong.(2004)sosiologi Teks Pengantar Dan Terapan. Surabaya: Prenada Media Group.

Paizaluddin, Ermalinda. (2013).Penelitian Tindakan Kelas Panduan Teoritis dan Praktis.Bandung: Alfabeta.

Shadily Hasan.(1993). Sosiologi Untuk Masyarakat Indonesia.Jakarta : Rineka Cipta

Soerjono Soekanto. (2012). Sosiologi Suatu Pengantar.Jakarta : PT. Raja Grafindo Persada. 
Sugiyono.(2012). Metode Penelitian Kombinasi (Mixed Methods).Bandung : Alfabeta.

Sujatmiko (2014).Batu Cincin dan Legendanya.Yogyakarta : Kamea Pustaka

Suyanto Bagong. (2013). Sosiologi Ekonomi.Jakarta : PT. Kharisma Putra Utama.

Waters.(1994). Teori Sosiologi Moderen.Surabaya : Yayasan Kesatuan Umat. 